\title{
JÚDICE, Nuno. As máscaras do poema. Lisboa: Aríon, 1998.
}

Ida Ferreira Alves

Universidade Federal Fluminense

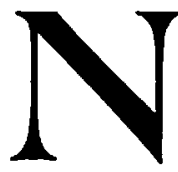

uno Júdice é, na poesia portuguesa das últimas décadas, um nome de reconhecida importância. É sobretudo um escritor preocu pado com o processo poético, com o lugar e a função da escrita, com os limites da linguagem e da literatura em nosso tempo de massificação $e$ globalização. Muitos são os títulos de poemas em todos os seus livros que confirmam essa motivação de trabalho e levam o seu leitor inevitavelmente a considerar a poesia sob a perspectiva crítica. Em todas as direções de sua escrita (e sua bibliografia ativa, a partir de 1972, já reúne cerca de quarenta títulos), o leitor acompanha reflexões estéticas e é levado ao questionamento sobre a permanência da arte na contemporaneidade, quando aparentemente ela não mais consegue intervir ou se fazer escutar em prol da condição humana. A obra de Nuno Júdice, na prática permanente de leitura crítica, interroga a modernidade e a polêmica pósmodernidade e discute, afinal, $o$ raio de ação da literatura.

A coesão entre os diferentes gêneros que trabalha (poesia, narrativa, teatro e ensaística) se dá exatamente pelo olhar crítico frente à escrita, sua e alheia, em língua portuguesa ou não. Leitor especializado de literatura, uma vez que também é professor de Letras da Universidade Nova de Lisboa, sua escrita ensaística e literária preocupa-se com a produção poética francesa do século XIX, que modelou a modernidade literária ocidental com poetas como Baudelaire, Mallarmé e Rimbaud, com outros poetas como Saint-John Perse e Francis Ponge, com a poética anglo-americana - Eliot, Pound, 
Cummings, com a poesia alemã Hölderlin e Rilke, além da literatura clássica latina, medieval e clássica portuguesa. Por isso, podemos dizer que Nuno Júdice pertence a esse grupo de poetas para os quais escrever é ler criticamente, e ler é buscar em outras escritas trajetórias modelares com as quais o poeta poderá melhor caminhar em seu próprio território de palavras. Em entrevista (ROZÁRIO, Denira. Palaura de poeta-Portugal. Rio de Janeiro: Civilização Brasileira, 1994. p.286), ao ser questionado se "A escrita depende da leitura?", Júdice respondeu que:

Ler e escrever sào duas atividades que se penetram e, por vezes, confundem. Escrevo porque muito do que leio a isso me estimula - ou porque me surge como um modelo que gostaria de atingir. Entendo o ul pictura poesis de Horácio nesta linha: a escrita do poema é, antes de mais nada, uma cópia dos mestres.

Na meditação contínua sobre - lugar e a ação do sujeito lírico, na transformação pluralizante do eu como personagens vários de uma história maior (incansavelmente narrada) que é a da própria literatura ocidental, o escritor e crítico está discutindo a leitura como exercício obrigatório de dialogismo para quem deseja compreender seu tempo, sua cultura, sua própria literatura nacional. Destacamos, dessa forma, em sua obra, como a prática de leitura crítica é recorrente, gerando poemas que se tornam reflexões estéticas complexas.

No entanto, sob o nosso ponto de vista, está em As Máscaras do Poema (1998), o material textual crítico mais conseqüente para entender os princípios que clirigem o plano de trabalho do poeta. Reúne artigos diversos: a maior parte é inédita e os outros textos já haviam sido publicados "em revistas ou publicações coletivas de acesso nem sempre fácil (nota final, p.265)". Também é dividido em sessões, cinco: Sobre poesia, Para uma releitura de Bernardim Ribeiro, Outros estudos (sobre Hölderlin, Manuel Laranjeira, Mário Sá Carneiro, Almada Negreiros, Camilo e Eça, Florbela Espanca, Mário Cesariny, Surrealismo, poesia e pintura, poesia e modernidade, poesia e narratividade), Algunspercursos contemporâneos (destacamos "Uma Casa Portuguesa", além de 
mais sete estudos sobre a linguagem poética de alguns poetas contemporâneos) e Poesia $e$ Tradução.

Obra de maior extensão, são aproximadamente 260 páginas de escrita crítica, constitui uma reflexão amadurecida sobre a ação poética, o poema, a poesia de outros poetas e, sem dúvida, a contemplação de sua própria perspectiva literária e o lugar de sua escrita poética. É, por conseguinte, uma obra fundamental que não afasta do scu horizonte reflexivo todo o trabalho poético que até entĩo o escritor-professorpoeta realizou, discutindo as suas balizas e núcleos teóricos.

O primeiro deles é o motivo da poesia, a persistência do poético. Na perspectiva do crítico, a poesia é uma reação ao mundo e se elabora na tensão $\mathrm{e}$ num drama entre sujeito e mundo. Não é discurso de salvaçĩo ou de harmonia, e sim processo verbal por meio do qual se enfrenta a crise da existência humana frente às certezals de sua destruição ou precariedade. Essa visĩo é sintetizada na idéia de anti-utopia:

Este $\dot{c}$, entào, o plano da antiutopia: aquele em que o homem, tomando consciência da sua condiçào mortal, procura a sua sobrevivência que é, acima de tudo, a permanência na memória que só existe na palavra que the da forma. (p.13)

A poesia como atividade de resistência põe o problema da memória no centro de sua atenção, pois a escrita institui um diálogo que não cessa de ser encetado a cada a proximação de um leitor, o qual, afinal, dá a razão de ser de qualquer texto. Logo, a idéia de uma poesia fechada em si, auto-contemplativa ou auto-referencial, é uma falácia que negaria o senticlo próprio do poético: a sua inserção na comunidade como linguagem de liberdade a permitir o confronto de versōes de mundo e de versões de sujeitos. O escritor afirma: "Trata-se de uma tensão que coloca no horizonte da poesia o próprio humano." (p.40) e essal declaraçāo defende a poesia como discurso que persiste como memória humanista frente à automatização, massificação e materialismo tecnológico.

No texto "As linguagens e as máscaras do poenua", a razão da poesia é seu tema central. E repetindo o que em diversals passalgens do livro é dito, escrever é 
buscar a identidade maior: ser homem num tempo inumano. A razão da poesia se encontra, portanto, na existência do sujeito $e$ isto é o segundo pólo fundamental do trabalho poético de Júdice. Escreve-se sempre para alguém, mas esse pronome indefinido não significa, muitas vezes, o outro fora do eu-escrevente, mas os outros que atuam nesse eu, numa experiência dramática interior que a poética pessoana magistralmente deu a conhecer. Júdice reflete com muita atenção sobre o sujeito da escrita e o sujeito da leitura, sobre o euescritor e o eu-leitor, vivenciando ambos os limites da ficção para chegar à seguinte ilação:

Então, para que o círculo se feche, aqui está: o leitor ideal é o próprio escritor, aquele que se pode dispensar a si próprio, e que procura de cada vez que escreve, criar um outro, desembaraçar-se do seu personagem ou, pelo menos, encontrar os outros rostos de si próprio. (p.53)

O status de sujeito ordenador do discurso tem implicações sérias na constituição do poema. A existência de um sujeito que doa a sua palavra e a de um sujeito que aceita recebê-la significam o estabelecimento de um acordo essencial para o exercício da linguagem: a escolha de uma perspectiva comum. A escrita ficcional é assim o resultado dessa perspectiva por meio da qual se olha o real, estabelecendo imagens diversas do que se contempla. O diálogo entre escritor e leitor é a discussão contínua das regras de perspectiva que a ficção utiliza.

No horizonte do poema está uma paisagem sempre em elaboração a partir do olhar do leitor. Por isso o poeta é, como diz Júdice, um mediador entre espaços, tempos e mundos, os do texto e os do leitor. Nessa paisagem, a metáfora é princípio ordenador, porque reúne as oposiçōes ou diferenças, estabelecendo-se como mecanismo cognitivo que permite a transformaçào do leitor frente à escrita, na medida em que o faz conhecer ou reconhecer mundos. Nessa direção, a metáfora é o resultado de um processo de interação entre linguagem e sujeitos (escritor, leitor) que a utilizam.

A poesia é, portanto, um discurso rigoroso e exigente, 
nada inocente, em relação às suas próprias estratégias de elaboração e ludibria facilmente aqueles que entendem o lirismo, a subjetividade, como transferência direta de emoção e sentidos. Ora, a concepção de que o poético é uma prática cognitiva une poetas e leitores numa "outra comunidade" a habitar um território que não se restringe ao solo nativo ou nacional.

Essa desterritorializaçĩo para se chegar a uma re-territorialização no domínio da linguagem poética é um dos pontos-chave da obra de Nuno Júdice. $A$ intensa preocupação com o poético parece excluir o mundo histórico real, mas o que se efetiva por meio desse posicionamento é a forte reflexão sobre um discurso que se auto-examina, buscando compreender sua presença naquele mesmo mundo.

Ao mesmo tempo, se a Nação é uma imagem construida por um grupo na sua linguagem comum, cada poeta afirma sua nacionalidade na potencialização de suá língua, na abertura que ela lhe permite para confrontar-se com as outras culturas, evidenciando-se as versōes que lhe são próprias, pois é confrontando as diferenças que se assume em definitivo o território de palavras que nos deu um mundo para habitar.

Obra instigante pelas questões suscitadas, é também um encontro informal entre o poeta, seus leitores e todos que desejam compreender o processo poético e sua importâncial em nosso tempo.

[...] De facto, é para assistir a esse milagre da criaçào poética que o poeta continua a escrever, mesmo que nào se trate sento de um pequeno milagre, em todo o caso, o único milagre a que nós, os habitantes de um mundo que perdeu já todos os deuses e mistérios, podemos ainda ter o direito de assistir. (p.57-58) 